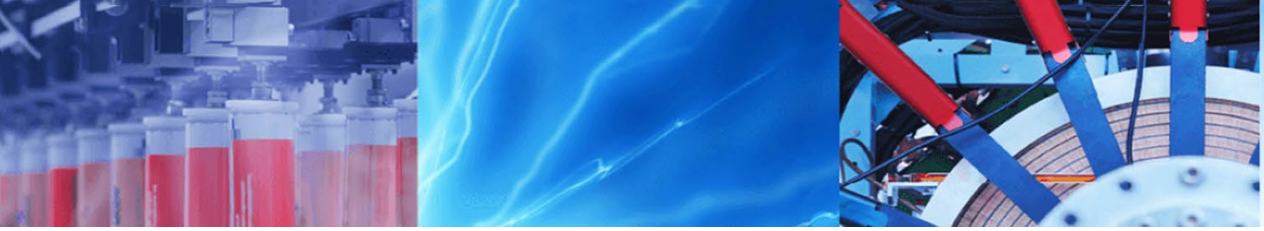

Research Article

\title{
Experimental investigation on fuel properties and engine characteristics of biodiesel produced from Eruca sativa
}

\author{
Sara Tayari ${ }^{1}$ (1) $\cdot$ Reza Abedi $^{2} \cdot$ Kambiz Tahvildari $^{3}$
}

Received: 10 October 2019 / Accepted: 28 November 2019 / Published online: 2 December 2019

(c) Springer Nature Switzerland AG 2019

\begin{abstract}
This paper aims to consider the potential of Eruca sativa (ES) crops, which is a plant with a short production cycle and drought tolerance, for biodiesel feedstock source and to compare exhaust emissions and engine performance of using its biodiesel blends with pure diesel. Thus, ES methyl ester was produced through a transesterification reaction by using $\mathrm{KOH}$ as a catalyst. The fatty acid composition of ES biodiesel was determined by FTIR and GC-MS analysis and its properties were compared with ASTM biodiesel standard and regular diesel. The GC-MS analysis showed that oleic and palmitic acids were the main compounds in ES methyl ester. Then, biodiesel blends were injected into a single-cylinder 4-stroke diesel engine at various speeds. Experimental tests revealed that using ES methyl ester led to reductions in $\mathrm{HC}$ and $\mathrm{CO}$ emissions substantially and NOx emissions moderately, whereas there was a minor rise in $\mathrm{CO}_{2}$ emissions. Moreover, a slight decrease in engine power and an increase in specific fuel consumption (5.3\%) occurred, which are acceptable due to the reduction of exhaust emissions. Based on the results, ES biodiesel has the capability to apply in $\mathrm{Cl}$ engines and to diminish emissions.
\end{abstract}

Keywords Eruca sativa $\cdot$ Methyl ester $\cdot$ GC-MS · FTIR · Exhaust emissions · Engine performance

$\begin{array}{ll}\text { Abbreviations } \\ \mathrm{B}(\mathrm{X}) & \text { X\% biodiesel }+(100-\mathrm{X}) \% \text { diesel } \\ \mathrm{Cl} & \text { Compression ignition } \\ \mathrm{CO} & \text { Carbon monoxide } \\ \mathrm{CO}_{2} & \text { Carbon dioxide } \\ \mathrm{ES} & \text { Eruca sativa } \\ \mathrm{FAME} & \text { Fatty acid methyl ester } \\ \mathrm{GHG} & \text { Greenhouse gas } \\ \mathrm{HC} & \text { Hydrocarbon } \\ \mathrm{KOH} & \text { Potassium hydroxide } \\ \mathrm{NOx} & \text { Nitrogen oxides } \\ \mathrm{PM} & \text { Particulate matter } \\ \mathrm{rpm} & \text { Revolutions per minute }\end{array}$

\section{Introduction}

Fossil fuel as a source of GHG has adverse effects on the atmosphere and is recognized as a cause of climate change and its severe impacts on human life. Hence, extensive investments and researches have been done to obtain suitable renewable sources of energy. Over the past few years, there has been substantial attention to biodiesel as an alternative energy source.

Several studies have been conducted to find efficient methods for producing biodiesel from different feedstocks. The transesterification process was used for the conversion of various sources of oils to methyl esters, such as waste oils [1-3], vegetable oils [4-7], animal fats [8-10], and algae or microalgae [11-13]. It was demonstrated that selecting a proper feedstock plays an important role

\footnotetext{
$\triangle$ Sara Tayari, Sara.tayari@gmail.com | ${ }^{1}$ Faculty of Environment and Energy, Islamic Azad University Science and Research Branch, Tehran, Iran. ${ }^{2}$ MLC Research and Development Center, MAPNA Group Co., Tehran, Iran. ${ }^{3}$ Faculty of Chemical Science, Islamic Azad University North Tehran Branch, Tehran, Iran.
} 
in the quality of biodiesel. Some researchers focused on the optimum conditions of the transesterification process for different catalysts and biodiesel feedstocks. Lin et al. [4] presented optimum conditions to produce crude rice bran biodiesel with a sulphuric acid catalyst. Their experimental tests were performed in optimum reaction at $60^{\circ} \mathrm{C}$ with methanol/RBO molar ratio 6:1 and $0.9 \mathrm{wt} . \%$ of $\mathrm{KOH}$ for $60 \mathrm{~min}$. Silitonga et al. [5] found that the best conditions for the transesterification of Schleichera oleosa oil were at $55^{\circ} \mathrm{C}$ with $1 \mathrm{wt} . \%$ of $\mathrm{KOH}$ and $\mathrm{NaOH}$ and $1 \mathrm{wt} . \%$ of methoxide as the catalyst for $90 \mathrm{~min}$. Vahid et al. [6] evaluated $\mathrm{MgO}$ as the active phase of the biodiesel production process and achieved the conversion of 95 percent of sunflower oil to biodiesel. Armenta et al. [8] found that sodium ethoxide was more effective than $\mathrm{KOH}$ for transesterification of fish oil. Cheng et al. [14] compared four solid acid catalysts to convert lipids of microalgae into fatty acid methyl esters (FAME), in which sulfonated graphene oxide had a maximum conversion efficiency among them. In Hossain et al. [15] investigation, microalgae biocrude extracted by hydrothermal liquefaction (HTL) contained the same oxygen and $10 \%$ lower calorific value compared to microalgae FAME. Kaisan et al. [16] compared specifications of cotton, jatropha and neem biodiesels. They established that heating values, cetane numbers, and flash points of all three feedstocks were consistent with standards.

Although several articles have demonstrated that using biodiesel in engines reduces gas emissions, some studies have reported different behavior for different biodiesel feedstocks. Experimental investigation on the engine fuelled with Jatropha methyl ester observed a substantial drop in $\mathrm{CO}$, whereas there was a slight growth in NOx emissions $[7,17]$. These results were different from that of using castor and soybean biodiesel into the diesel engine since $\mathrm{CO}$ and $\mathrm{HC}$ emissions increased [18]. Randazzo et al. [19] considered soybean biodiesel blends and the effects of anhydrous ethanol as an additive. Their results revealed that by increasing the biodiesel concentration in the fuel blend, $\mathrm{CO}$ and $\mathrm{HC}$ emissions declined, while $\mathrm{CO}_{2}$ and $\mathrm{NOx}$ emissions rose. Besides, anhydrous ethanol could reduce $\mathrm{NOx}$ and $\mathrm{CO}_{2}$ emissions. Based on the result of Buyukkaya [20] tests, for rapeseed biodiesel with B5 and B20 proportions, $\mathrm{CO}$ emissions were $32 \%$ lower than that of pure diesel, whereas fuel consumption increased by $11 \%$. Vedaraman et al. [21] injected palm biodiesel in a diesel engine and found that $\mathrm{CO}$ and $\mathrm{HC}$ emissions reduced $28 \%$ and $30 \%$ for B20 blend, respectively, and NOx emissions were almost the same as diesel fuel. In a study by Li et al. [22], heteropoly acid salt was used as the catalyst for Eruca sativa Gars biodiesel. In their tests, while $\mathrm{HC}$ and $\mathrm{CO}$ emissions were less than pure diesel, higher BSFC and NOx were observed. In another investigation, a common-rail diesel engine with $\mathrm{B} 30$ and $\mathrm{B} 70$ blends of waste cooking oil biodiesel was tested by Lapuerta et al. [23]. They found a slight rise in NOx emissions and a sharp reduction in total HC and smoke opacity emissions. Dhamodaran et al. [24] compared biodiesels of rice bran, cottonseed, and neem oils with varying degrees of unsaturation. All of those feedstocks reduced the $\mathrm{CO}$ and PM emissions. In another study, Márcio et al. [25] observed that the lowest $\mathrm{CO}_{2}$ emissions with waste frying oil and palm biodiesels occurred in lower biodiesel concentrations while soybean biodiesel had different behavior. Jaliliantabar et al. [26] compared physicochemical properties, combustion and emission characteristics of coffee, brassica, and cardoon biodiesels in a $\mathrm{Cl}$ engine. Their experimental results showed that different characteristics of methyl ester had different effects on the performance, emissions and combustion parameters of the engine. In addition, the oxygen content of the brassica biodiesel was considerably higher compared with cardoon and coffee biodiesels which reduced the $\mathrm{CO}$ and $\mathrm{HC}$ emissions. Maps of performance and emissions with using waste cooking oil biodiesel observed that $\mathrm{HC}$ emissions were highly related to engine speed; however, $\mathrm{CO}$ and PM depended on engine load [27]. Besides, some researchers [28] modeled a diesel engine using biodiesel with the artificial neural network to predict brake power, fuel consumption, and exhaust emissions.

Most of the plants studied in the articles are not capable of growing on drought or disturbed ground and some of them are in competition with food resources such as soybean, castor, palm, and cottonseed. Eruca sativa which is currently cultivated as a native plant in west Asia, Italy, Pakistan, and India is expected to be a potential feedstock for biofuel production, due to its adequate oil contents. Furthermore, Eruca sativa has crops with a short production cycle and drought-tolerant capacity. Literature reviews show that numerous researches have been carried out on producing biodiesel from various feedstocks, so far though limited studies consider ES methyl ester parameters such as optimum production and the influence of biodiesel on performance and emissions of the engine in different blends. In this study, quantities of methyl ester were produced from ES oils with the $\mathrm{KOH}$ catalyst and the main parameters including the molar ratio of methanol, temperature, and reaction time were considered. Then, ES biodiesel properties were determined for suitability in $\mathrm{Cl}$ engines and compared with ASTM D6571 standard. In addition, the effects of the operational range of speed/ load on engine performance and emissions were investigated with six different blends of ES biodiesel and compared with neat diesel. 


\section{Experimental setup and procedure}

This experimental study has been done through three consecutive stages including methyl ester production from ES oil, assessment of physicochemical properties of ES biodiesel, and determining engine exhaust emissions and performance.

In a Soxhlet extractor, the boiling $\mathrm{N}$-hexane as a solvent was used to extract oil from ES seeds for about 5-6 $\mathrm{h}$ at $70^{\circ} \mathrm{C}$. By this method, the maximum efficiency of oil extraction was 35 percent. Figure 1 presents the process description of methyl ester production from ES oil. The homogeneous catalysts are the common substance for the transesterification process of vegetable oils [11]. In this study, potassium hydroxide ( $\mathrm{KOH} 99 \%)$ was used. In the transesterification method, ES oil (triglycerides) reacted with an alcohol such as ethanol, methanol, propanol, and butanol in the presence of a catalyst. Owing to a reasonable price and more appropriate chemical and physical properties, methanol was superior. Thus, a mixture of potassium hydroxide and methanol with a molar ratio of 1:6 was added to the reaction flask with the non-stop stirring at the speed of $400 \mathrm{rpm}$. The optimum state of transesterification reaction was obtained with $0.5 \mathrm{~g} \mathrm{KOH}$ catalyst in the presence of methanol at a temperature of $65^{\circ} \mathrm{C}$ for $2 \mathrm{~h}$. It was observed that maximum biodiesel production was $94 \%$. Contents of the flask were poured into the separating funnel for several hours at room temperature until the glycerine as a valuable by-product of the ester was isolated. The final product was leached for isolation of the $\mathrm{KOH}$ catalyst and removing the produced soap. Hence, the product and distilled water (30\% of oil weight) were stirred at $60-70{ }^{\circ} \mathrm{C}$ for $2 \mathrm{~min}$ to solve the produced soaps. Then, it was poured into a separation funnel to separate the water. This operation was continued until the product had a natural $\mathrm{pH}$ level. The litmus paper was used to ensure complete neutralization. The water which remained in the form of an emulsion was removed with heat treatment.

Experimental tests were performed for B2, B5, B10, $B 15$, and $B 20$ blends and compared with pure diesel fuel (B0). These tests were accomplished on a singlecylinder direct injection diesel engine in the Laboratory of Tarbiat Modares University. The experimental setup scheme and the technical specifications of the engine are shown in Fig. 2 and Table 1. The engine was coupled with a dynamometer and its load was measured by a load sensor device. Engine load could be set with a torque controller and shown on the screen. Performance and emissions of the engine were monitored for all ES biodiesel blends at no-load and full-load operations with various engine speeds. In order to improve the accuracy of the experiments, oil filter, lubrication oil, and air filter were renewed and the injection pressure was calibrated in every engine test. Furthermore, the $\mathrm{Cl}$ engine was allowed to run for sufficient duration at the beginning of each test to consume the remaining fuel from previous tests. Emission Tester MGT5 which could measure the CO, $\mathrm{CO}_{2}, \mathrm{HC}$, and NOx emissions, was used for determining exhaust emissions of the $\mathrm{Cl}$ engine.
Fig. 1 Process description of ES biodiesel production

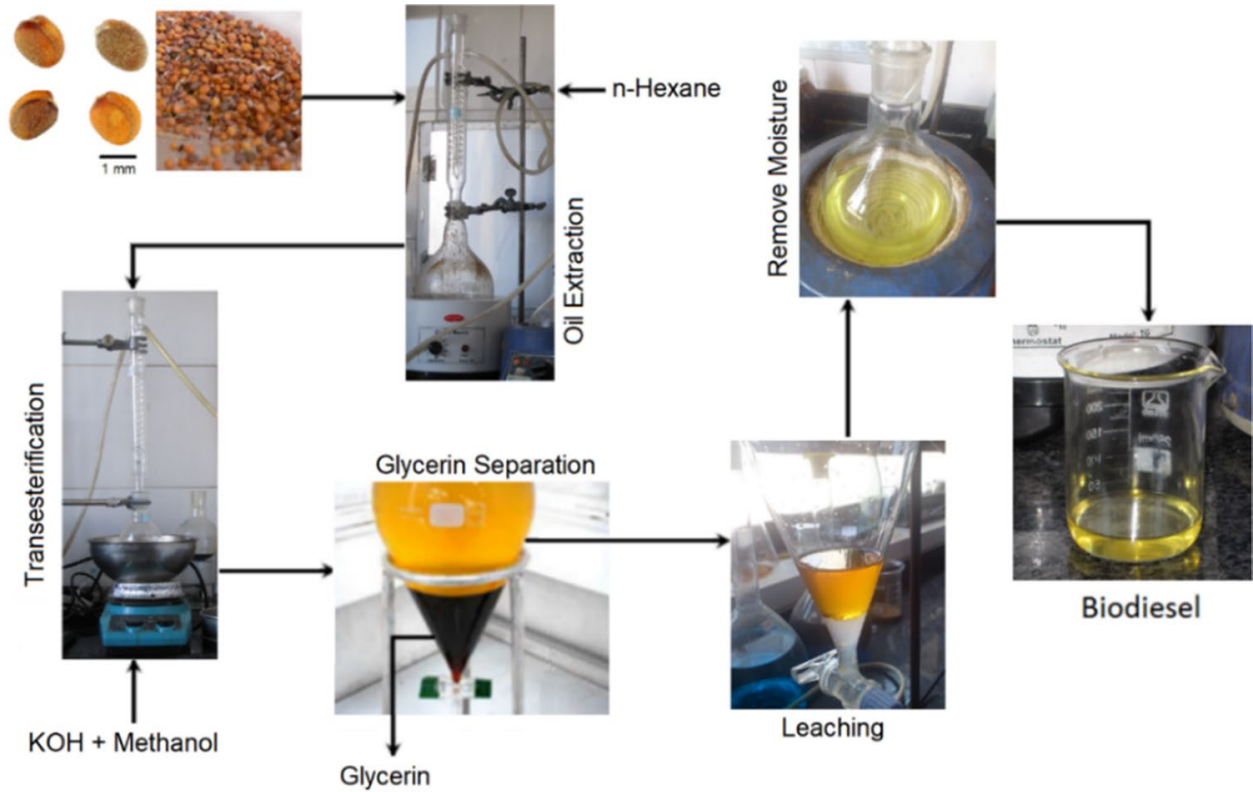

SN Applied Sciences A SPRINGER NATURE journa 
Fig. 2 a Schematic diagram of experimental setup, b Engine laboratory

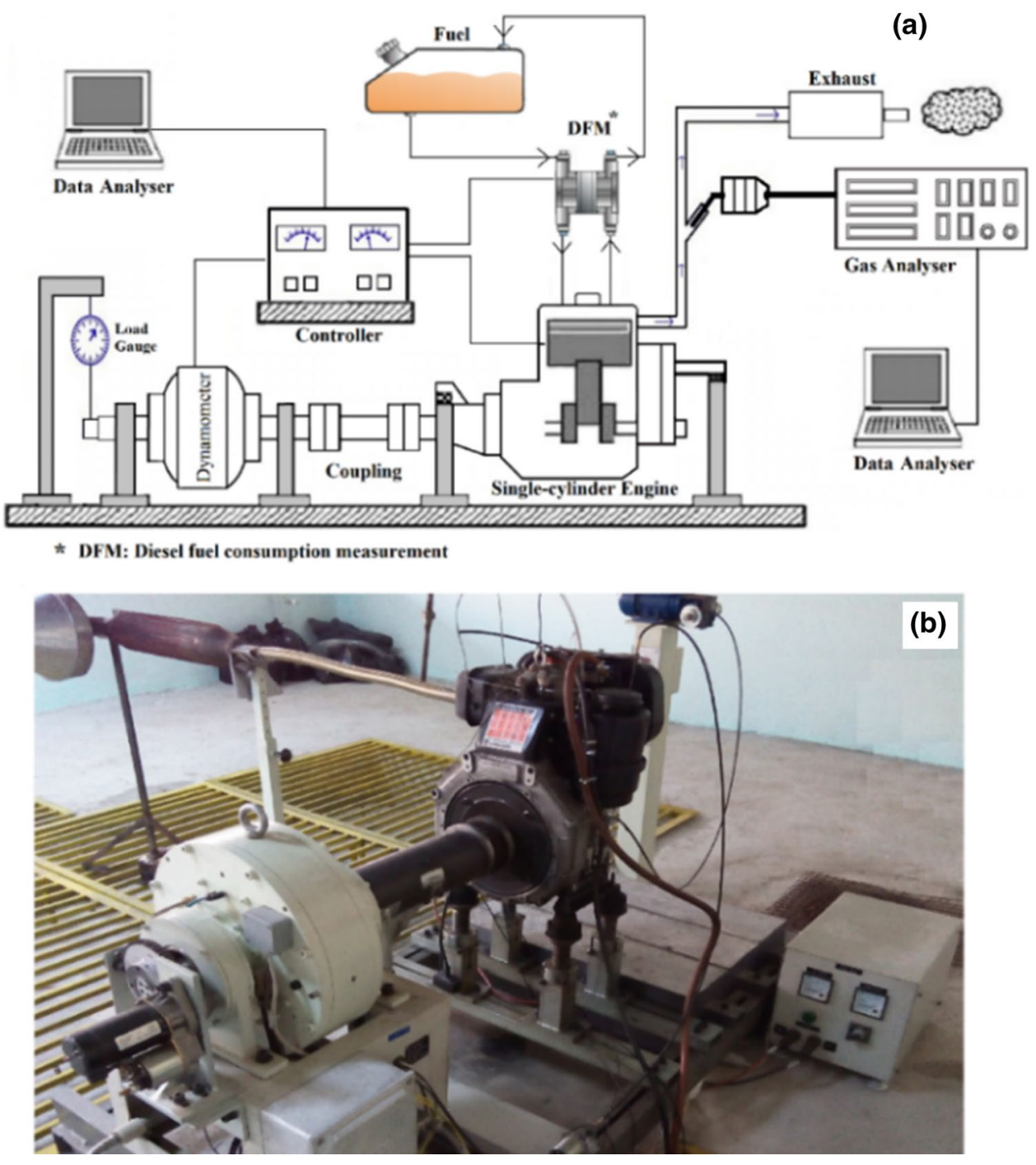

Table 1 Technical specifications of the engine

\begin{tabular}{ll}
\hline Engine model & $\begin{array}{l}3 \text { LD 510 Lombar- } \\
\text { dini }\end{array}$ \\
\hline Engine type & $\begin{array}{l}\text { 4-Stroke, Direct } \\
\text { Injection, Diesel } \\
\text { engine }\end{array}$ \\
Cylinder number & 1 \\
Stroke volume (cc) & 510 \\
Compression ratio & $17.5: 1$ \\
Maximum power (HP@rpm) & $12 @ 3000$ \\
Maximum torque (N-m@rpm) & $32.8 @ 1800$ \\
Bore $\times$ Stroke (mm) & $85 \times 90$ \\
Cooling system & Forced air cooling \\
\hline
\end{tabular}

Table 2 Properties of ES biodiesel, ASTM standard and diesel

\begin{tabular}{llll}
\hline Property & ASTM standard & Diesel & ES Biodiesel \\
\hline Flash point $\left({ }^{\circ} \mathrm{C}\right)$ & $130, \mathrm{~min}$ & 88 & 185 \\
Pour point $\left({ }^{\circ} \mathrm{C}\right)$ & -10 to -15 & -7 & -10 \\
Density $\left(\mathrm{g} / \mathrm{cm}^{3}\right)$ & $0.87-0.90$ & 0.83 & 0.87 \\
Viscosity $\left(\mathrm{mm}^{2} / \mathrm{s}\right)$ & $1.9-6.0$ & 3.1 & 4.192 \\
Sulfur content $(\%)$ & $0.15, \mathrm{max}$ & $\mathrm{N} / \mathrm{A}$ & 0 \\
Acid value $(\mathrm{mg} \mathrm{KOH} / \mathrm{g})$ & 0.8 & $\mathrm{~N} / \mathrm{A}$ & 0.11 \\
Cetane number & $47, \mathrm{~min}$ & 46.2 & 47.5 \\
Calorific value $(\mathrm{MJ} / \mathrm{kg})$ & N/A & 46.8 & 43.76 \\
\hline
\end{tabular}




\section{Results and discussion}

\subsection{Fuel characterization}

The comparison between the properties of ES biodiesel, pure diesel, and ASTM standard are shown in Table 2. It can be seen that kinematic viscosity, calorific value, pour point, and flashpoint of ES biodiesel are within the acceptable range of the standard. The heating value of ES methyl ester is $6.6 \%$ lower than pure diesel $\left(46.8 \mathrm{~kJ} \mathrm{~g}^{-1}\right)$. In addition, the lower acid value of ES biodiesel compared with the standard represents the least potential for corrosion of the engine.

The FTIR spectrum of methyl ester reveals the presence of alcohol, alkyne, alkene, methyl, and aromatic compounds in ES methyl ester. Figure 3 illustrates the FTIR spectrum of the ES biodiesel. This FTIR spectrum almost matches the methyl stearate ones, and the only difference occurs in 3006 and 1654, which has no peak point in this area due to the lack of $C=C$ group in methyl stearate.

The compounds of ES methyl ester (C16-C18 range) are identified by GC-MS analysis and shown in Table 3. The GC-MS analysis represents that oleic acid (C18:1), linoleic acid (C18:2), and palmitic acid (C16:0) are the main compounds in the ES methyl ester. Longer FAME length and more Oleic acid content lead to less NOx and better oxidative stability in combustion [29].
Table 3 Fatty acid compositions of ES methyl ester

Fatty acids

Contents ES methyl ester

(\%)

$\begin{array}{lr}\text { Palmitic (C16:0) } & 28.3 \\ \text { Palmitoleic (C16:1) } & 0.4 \\ \text { Stearic (C18:0) } & 2.5 \\ \text { Oleic (C18:1) } & 28.3 \\ \text { Linoleic (C18:2) } & 22.7 \\ \text { Linolenic (C18:3) } & 12.4 \\ \text { Other } & 5.4\end{array}$

\subsection{Exhaust emissions results}

Emissions of engine depend on biodiesel feedstock and pure diesel which blends with it. Therefore, experimental engine tests were carried out to study the effects of various ES biodiesel blends on $\mathrm{CO}, \mathrm{CO}_{2}, \mathrm{NOx}$, and $\mathrm{HC}$ emissions. Figure 4 depicts the results of $\mathrm{HC}$ emissions for each biodiesel blend at different engine speed/loads. As can be seen, under no-load operation, HC emissions are increased by raising the engine speed. Figure $4 \mathrm{~b}$ illustrates an opposite behavior at full-load. It can be explained by the fact that at high engine speed and full-load condition, the air-fuel ratio is less than the stoichiometric value and combustion is more complete [30]. Under no-load operation, $\mathrm{HC}$ emissions of B2, B10,
Fig. 3 FTIR spectrum of the ES biodiesel

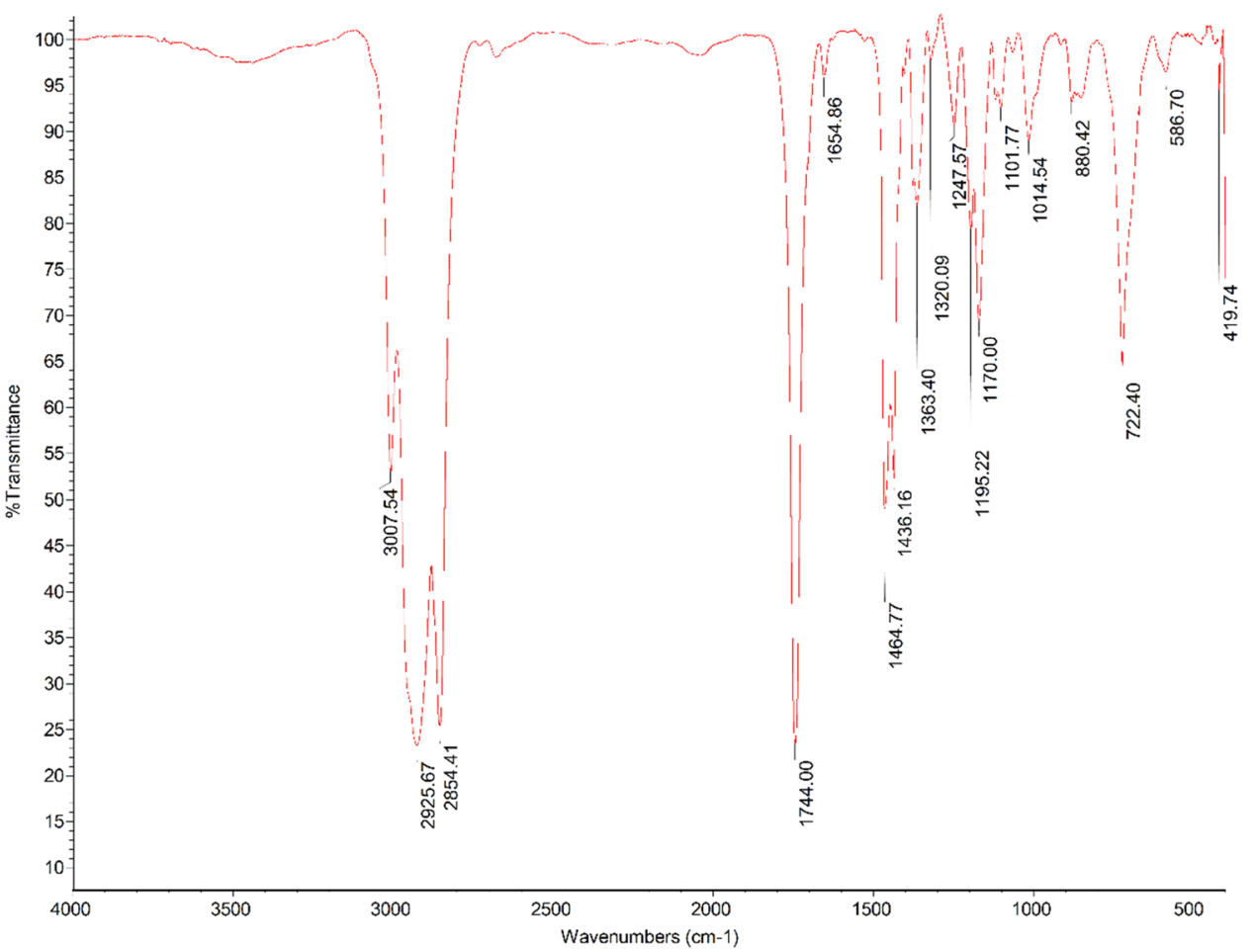

SN Applied Sciences 
Fig. $4 \mathrm{HC}$ emissions of ES biodiesel blends at a no-load, b full-load operations
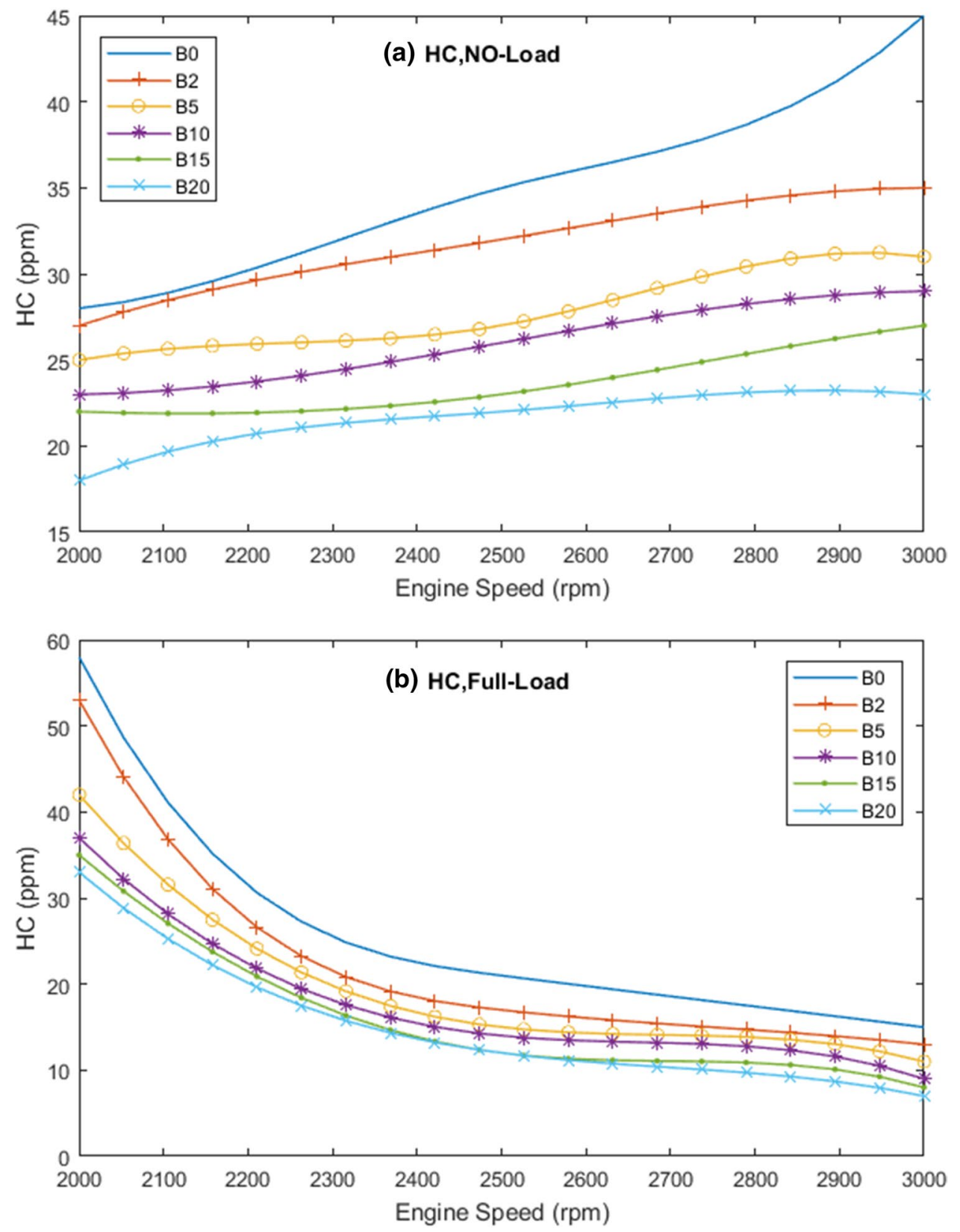

and B20 were respectively by $22.1 \%, 35.6 \%$, and $48.3 \%$ lower than pure diesel at $3000 \mathrm{rpm}$. Besides, the average reduction of $\mathrm{HC}$ emissions of $\mathrm{B} 5$ and $\mathrm{B} 20$ were respectively $20.4 \%$ and $39.8 \%$. Under full-load operation, these amounts were $19.3 \%, 28.2 \%$, and $38.2 \%$, respectively. Several studies have reported the reduction of $\mathrm{HC}$ emissions by using different biodiesels [31-33].

Figure 5 shows the $\mathrm{CO}$ emissions of diesel-biodiesel blends at various engine speeds. It was observed that $\mathrm{CO}$ emissions were decreased by increasing engine speed and biodiesel content. At no-load condition, the average $\mathrm{CO}$ emissions of $\mathrm{B} 2, \mathrm{~B} 10$, and $\mathrm{B} 20$ were reduced respectively by $3.4 \%, 9.2 \%$, and $14.1 \%$ in comparison with pure diesel. Under full-load operation, the average reductions of these amounts were respectively $12.5 \%, 22.1 \%$, and $30.9 \%$. Similar results were reported by Hirkude [31], Park et al. [34], and Alptekin [35]. Among the reasons for the 
Fig. $5 \mathrm{CO}$ emissions of ES biodiesel blends at a no-load, b full-load operations
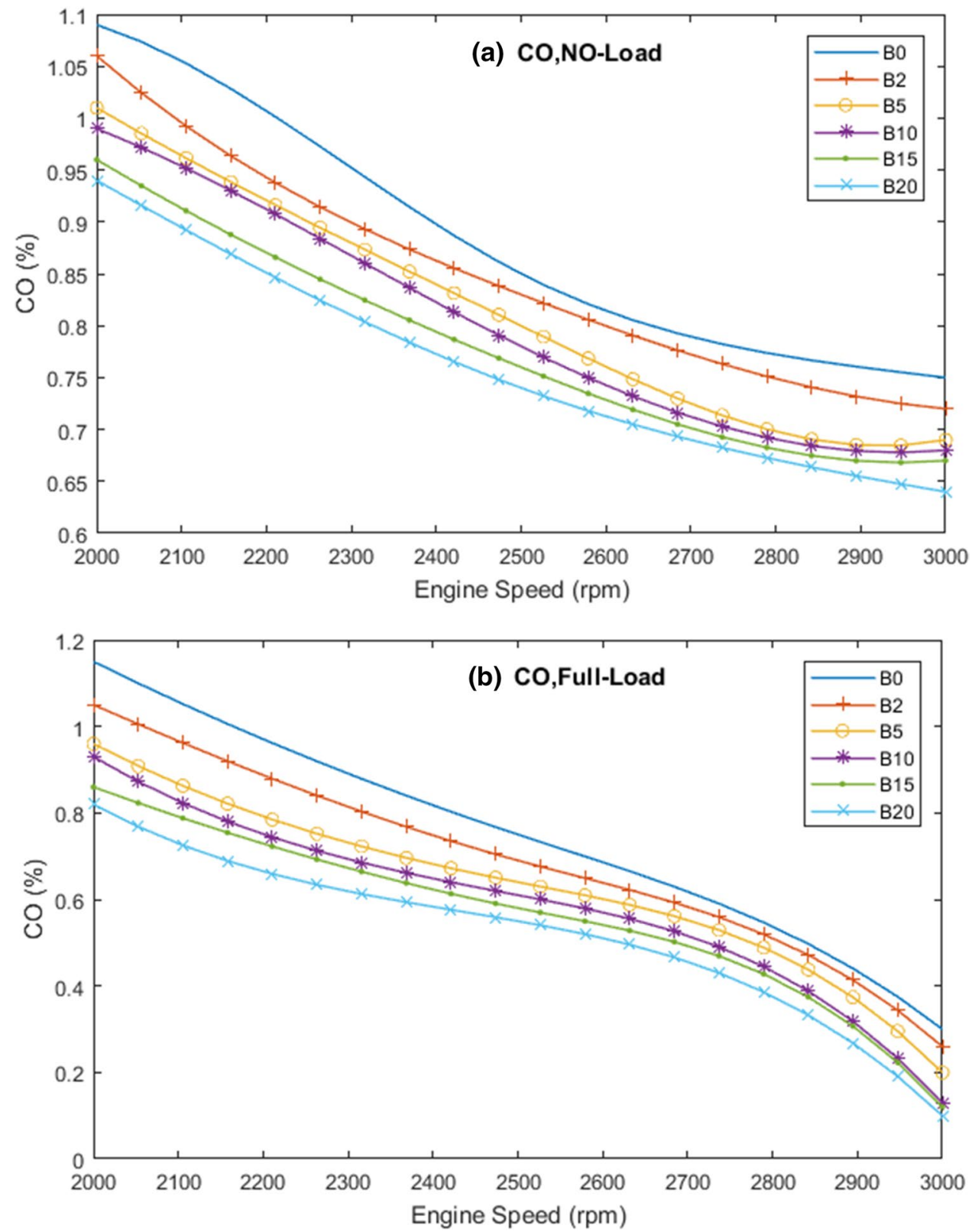

reduction of $\mathrm{CO}$ emissions, the higher oxygen content and cetane number of biodiesel can be mentioned.

$\mathrm{CO}_{2}$ emissions are the result of complete combustion of fuel. Figure 6 depicts the $\mathrm{CO}_{2}$ emissions for each ES biodiesel blends at different speeds. As can be seen, the amount of $\mathrm{CO}_{2}$ emissions has an opposite behavior compared to $\mathrm{CO}$ emissions and increases by raising the percentage of ES biodiesel blends. Under no-load condition, the average $\mathrm{CO}_{2}$ emissions of $\mathrm{B} 2, \mathrm{~B} 10$, and $\mathrm{B} 20$ increased respectively by $9.3 \%, 12.6 \%$, and $14.7 \%$. These amounts were respectively $4.1 \%, 8.4 \%$, and $10.9 \%$ at full-load operation. While $\mathrm{CO}_{2}$ emissions of ES biodiesel combustion are increased, the production chain of this plant reduces the overall GHG emissions. Eruca sativa plant is a leaf vegetable, which can adsorb $\mathrm{CO}_{2}$ during the photosynthesis process. The photosynthetic rate of this plant without any treatment is $8.94 \mu \mathrm{mol} \mathrm{CO} \mathrm{m}^{-2} \mathrm{~s}^{-1}$ at $25^{\circ} \mathrm{C}$ and $1 \mathrm{~atm}$ [36].

NOx emissions are shown in Fig. 7 at different speed/ loads by using ES biodiesel blends and pure diesel. Under no-load condition, the average amounts of NOx emissions 
Fig. $6 \mathrm{CO}_{2}$ emissions of ES biodiesel blends at a no-load, b full-load operations
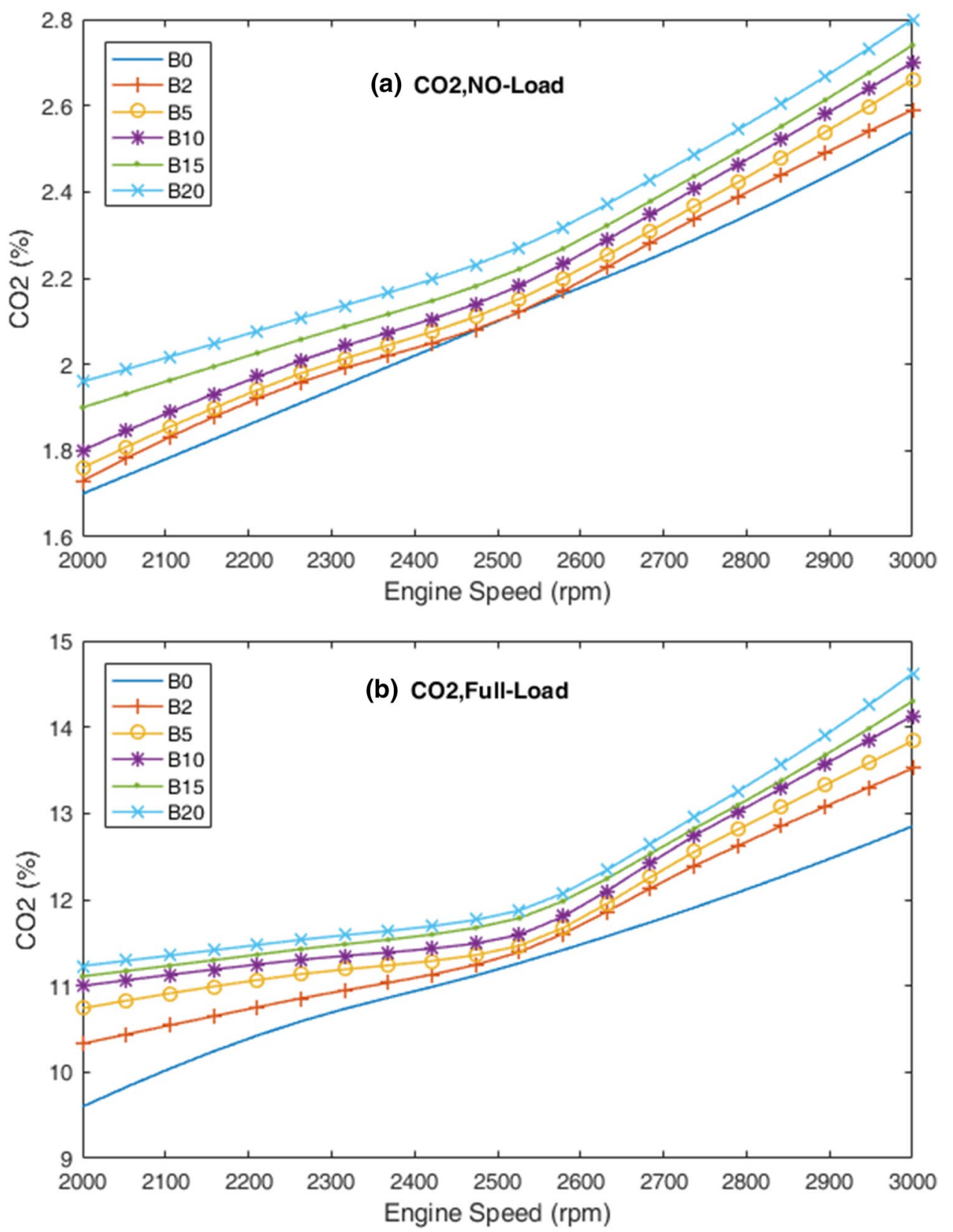

of B2-B20 blends declined by $2-16.4 \%$ compared with pure diesel at 2000-3000 rpm. These amounts were 1.79.3\% lower than of pure diesel at full-load. The amount of oxygen contained in ES biodiesel is an important factor for the formation of NOx since this factor eventuates in growth in temperature due to the excessive oxidation of hydrocarbons. High oxygen level leads to a rising temperature during combustion and increases NOx emissions [37]. Besides, a high cetane number of ES biodiesel caused the earlier start of combustion, which reduced the amount of fuel taking part in premixed combustion and resulted in the reduction of NOx emissions [27].

\subsection{Engine performance results}

The performance of a diesel engine is one of the major concerns for using any alternative fuel. Figures 8 and 9 illustrate the engine power and torque at different speeds. As can be seen in Fig. 8, there was a marginal fall in the engine torques by using different blends of ES biodiesel. 
Fig. 7 NOx emissions of ES biodiesel blends at a no-load, b full-load operations
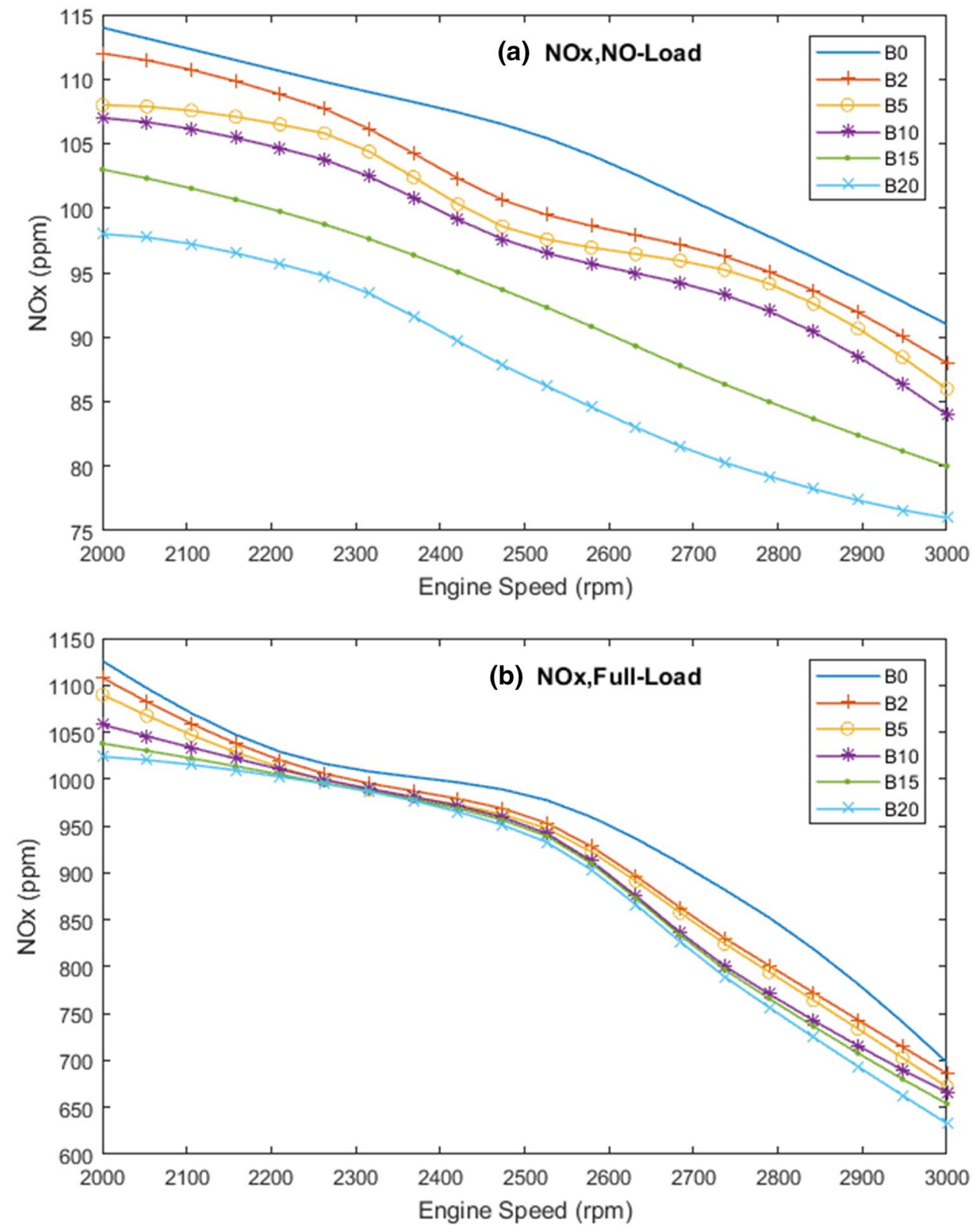

The engine torque for $\mathrm{B} 20$ was $27.88 \mathrm{Nm}$ at $2000 \mathrm{rpm}$, which was an evidence for a 3.3\% drop comparing with pure diesel. The average torque for B2, B10, and B20 were respectively $1.1 \%, 2.9 \%$, and $4.5 \%$ lower than pure diesel. The engine power had a similar trend for ES biodiesel blends. By using B2, B10, and B20, the engine power decreased by $1.0 \%, 3.2 \%$, and $4.3 \%$, respectively. Due to the lower calorific value and higher viscosity of ES methyl ester, power and torque of the engine were lower than pure diesel [38].
Fuel consumption is shown in Fig. 10 for diesel-biodiesel blends. Under no-load operation, there was not a significant difference between pure diesel and ES biodiesel blends. However, at full-load condition, the dissimilarity of fuel consumption rose by increasing the engine speed and the percentage of ES biodiesel blends. The highest consumption belonged to $\mathrm{B} 20$ by $2436 \mathrm{cc} \mathrm{hr}^{-1}$ at $3000 \mathrm{rpm}$. The fuel consumption of B2, B10, and B20 increased by $1 \%, 3.1 \%$ and $5.3 \%$ in comparison with pure diesel, respectively. 
Fig. 8 Engine torque of ES biodiesel blends at full-load operation
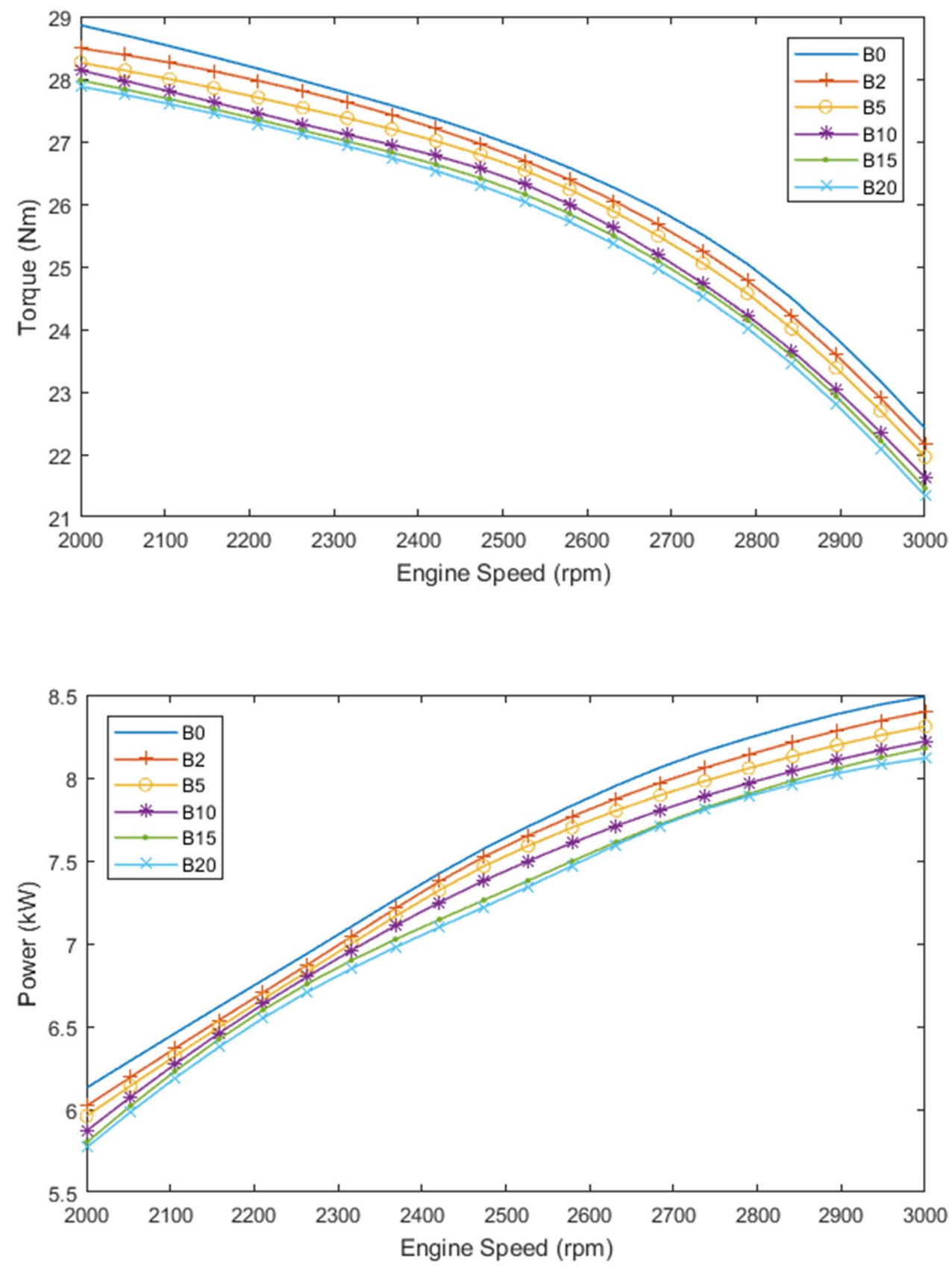

Fig. 9 Engine power of ES biodiesel blends at full-load operation
Figure 11 illustrations exhaust gas temperature for ES biodiesel blends at full-load operation. It was observed that the peak of exhaust gas temperature belonged to pure diesel at $3000 \mathrm{rpm}$ with $707^{\circ} \mathrm{C}$. This amount for the B20 blend was about 3.5\% less than pure diesel. The higher cetane number of ES methyl ester can cause shorter ignition delay; thus, combustion occurs more rapidly and makes a higher exhaust gas temperature [27].

\section{Conclusions}

This paper considered the production of ES methyl ester as a new feedstock of biofuel. The maximum efficiency of ES biodiesel production was obtained by the transesterification reaction at $0.5 \mathrm{~g} \mathrm{KOH}$ catalyst in the presence of methanol at a temperature of $65^{\circ} \mathrm{C}$. By comparing the physicochemical properties of ES biodiesel with ASTM 
Fig. 10 Consumption of ES biodiesel blends at a no-load, b full-load operations
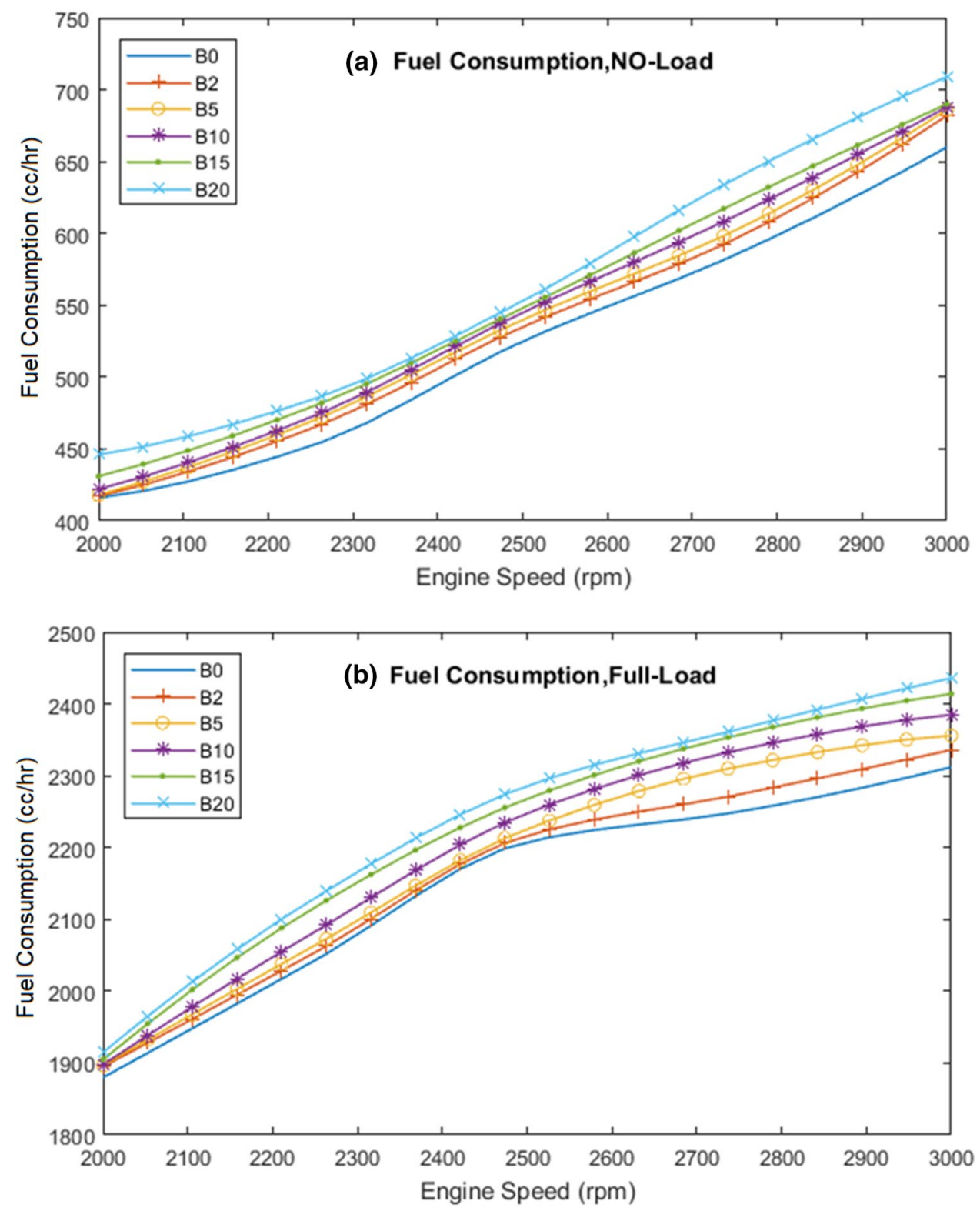

standard, it was determined that ES biodiesel could be used as a reliable alternative fuel. Then, performance and emissions of the engine fuelled with various blends of ES methyl ester were measured at different speeds under full-load and no-load operations and compared with neat diesel. Based on the experimental results, the following conclusions are obtained for B20 ES biodiesel blend compared with pure diesel at full-load operation:

- $\mathrm{CO}$ and $\mathrm{HC}$ emissions were respectively $30.9 \%$ and $38.2 \%$ lower.
- There was a marginal decrease in NOx emissions by $9.3 \%$.

- $\mathrm{CO}_{2}$ emissions were $10.9 \%$ higher than that of pure diesel.

- The power and obtained torque were slightly lower (4.3\%).

In conclusion, ES biodiesel can be used as a partial diesel substitute without modifications in the engine and is particularly attractive from an environmental perspective, which reduces engine emissions. 
Fig. 11 Exhaust gas temperature of ES biodiesel blends at full-load operation

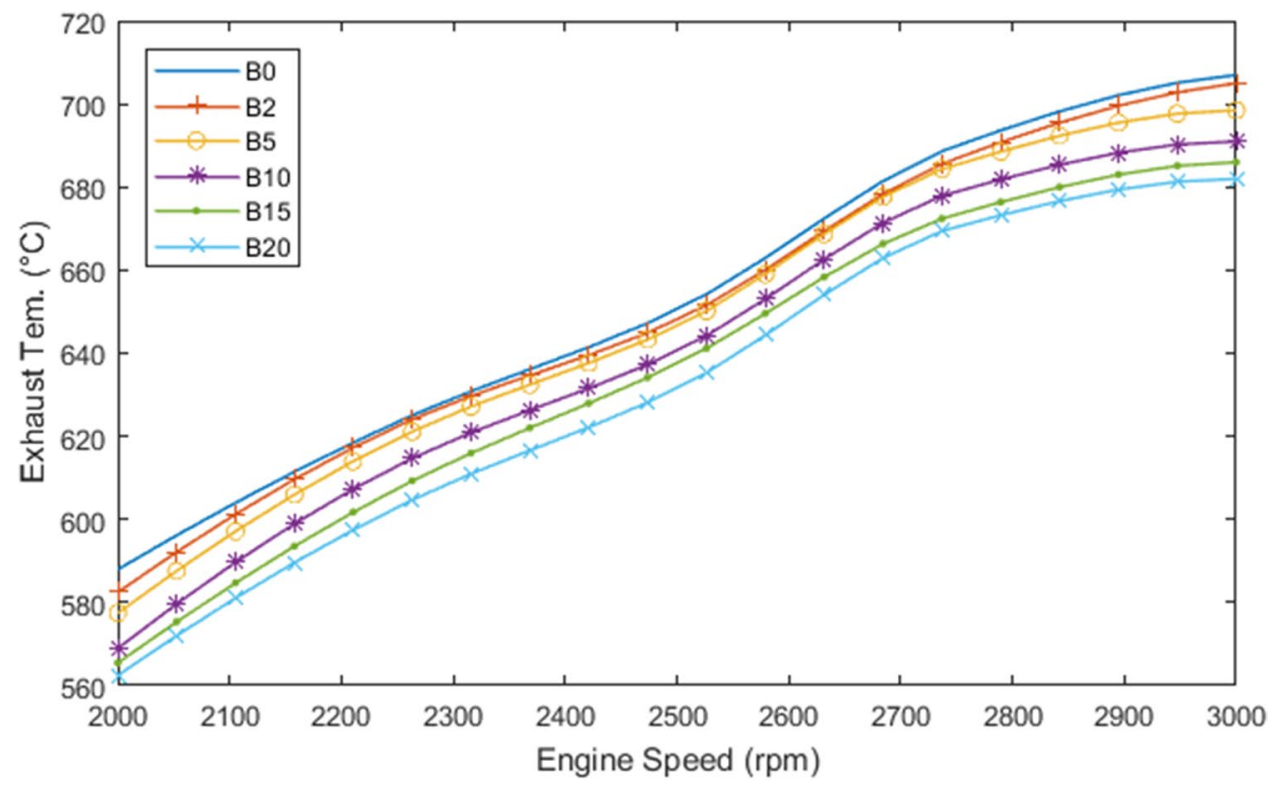

Acknowledgements The authors are thankful for the opportunities in order to use the laboratories in "Islamic Azad University, Tehran North Branch, Faculty of Chemistry" and "Tarbiat Modares University, School of Agriculture".

\section{Compliance with ethical standards}

Conflict of interest The authors declare that they have no conflict of interest.

\section{References}

1. Talebian-Kiakalaieh A, Amin NAS, Mazaheri H (2013) A review on novel processes of biodiesel production from waste cooking oil. Appl Energy 104:683-710. https://doi.org/10.1016/j.apene rgy.2012.11.061

2. Singh V, Bux F, Sharma YC (2016) A low cost one pot synthesis of biodiesel from waste frying oil (WFO) using a novel material, $\beta$-potassium dizirconate ( $\beta$-K2Zr2O5). Appl Energy 172:23-33. https://doi.org/10.1016/j.apenergy.2016.02.135

3. Santya G, Maheswaran T, Yee KF (2019) Optimization of biodiesel production from high free fatty acid river catfish oil (Pangasius hypothalamus) and waste cooking oil catalyzed by waste chicken egg shells derived catalyst. SN Appl Sci 1(2):152. https ://doi.org/10.1007/s42452-018-0155-z

4. Lin L, Ying D, Chaitep S, Vittayapadung S (2009) Biodiesel production from crude rice bran oil and properties as fuel. Appl Energy 86(5):681-688. https://doi.org/10.1016/j.apene rgy.2008.06.002

5. Silitonga AS, Masjuki HH, Mahlia TMI, Ong HC, Kusumo F, Aditiya HB, Ghazali NNN (2015) Schleichera oleosa L oil as feedstock for biodiesel production. Fuel 156:63-70. https://doi.org/10.1016/j. fuel.2015.04.046

6. Vahid BR, Haghighi M (2017) Biodiesel production from sunflower oil over MgO/MgAl2O4 nanocatalyst: effect of fuel type on catalyst nanostructure and performance. Energy Convers Manage 134:290-300. https://doi.org/10.1016/j.encon man.2016.12.048
7. Tesfay AH, Asfaw SH, Bidir MG (2019) Comparative evaluation of biodiesel production and engine characteristics of Jatropha and Argemone Mexicana oils. SN Applied Sciences 1(9):1075. https ://doi.org/10.1007/s42452-019-1075-2

8. Armenta RE, Vinatoru M, Burja AM, Kralovec JA, Barrow CJ (2007) Transesterification of fish oil to produce fatty acid ethyl esters using ultrasonic energy. J Am Oil Chem Soc 84(11):1045-1052. https://doi.org/10.1007/s11746-007-1129-2

9. Varuvel EG, Mrad N, Tazerout M, Aloui F (2012) Assessment of liquid fuel (bio-oil) production from waste fish fat and utilization in diesel engine. Appl Energy 100:249-257. https://doi. org/10.1016/j.apenergy.2012.05.035

10. Okwundu OS, El-Shazly AH, Elkady M (2019) Comparative effect of reaction time on biodiesel production from low free fatty acid beef tallow: a definition of product yield. SN Appl Sci 1(2):140. https://doi.org/10.1007/s42452-018-0145-1

11. Huang J, Xia J, Jiang W, Li Y, Li J (2015) Biodiesel production from microalgae oil catalyzed by a recombinant lipase. Biores Technol 180:47-53. https://doi.org/10.1016/j.biortech.2014.12.072

12. Mathimani T, Kumar TS, Chandrasekar M, Uma L, Prabaharan D (2017) Assessment of fuel properties, engine performance and emission characteristics of outdoor grown marine Chlorella vulgaris BDUG 91771 biodiesel. Renew Energy 105:637-646. https ://doi.org/10.1016/j.renene.2016.12.090

13. Patil PD, Reddy H, Muppaneni T, Deng S (2017) Biodiesel fuel production from algal lipids using supercritical methyl acetate (glycerin-free) technology. Fuel 195:201-207. https://doi. org/10.1016/j.fuel.2016.12.060

14. Cheng J, Qiu Y, Zhang J, Huang R, Yang W, Fan Z (2017) Conversion of lipids from wet microalgae into biodiesel using sulfonated graphene oxide catalysts. Biores Technol 244:569-574. https://doi.org/10.1016/j.biortech.2017.07.142

15. Hossain FM, Rainey TJ, Ristovski Z, Brown RJ (2018) Performance and exhaust emissions of diesel engines using microalgae FAME and the prospects for microalgae HTL biocrude. Renew Sustain Energy Rev 82:4269-4278. https://doi.org/10.1016/j. rser.2017.06.026

16. Kaisan MU, Anafi FO, Nuszkowski J, Kulla DM, Umaru S (2017) Calorific value, flash point and cetane number of biodiesel from cotton, jatropha and neem binary and multi-blends with diesel. Biofuels. https://doi.org/10.1080/17597269.2017.1358944 
17. Ong HC, Masjuki HH, Mahlia TMI, Silitonga AS, Chong WT, Yusaf T (2014) Engine performance and emissions using Jatropha curcas, Ceiba pentandra and Calophyllum inophyllum biodiesel in a $\mathrm{Cl}$ diesel engine. Energy 69:427-445. https://doi.org/10.1016/j. energy.2014.03.035

18. Valente OS, Da Silva MJ, Pasa VMD, Belchior CRP, Sodré JR (2010) Fuel consumption and emissions from a diesel power generator fuelled with castor oil and soybean biodiesel. Fuel 89(12):36373642. https://doi.org/10.1016/j.fuel.2010.07.041

19. Randazzo ML, Sodré JR (2011) Exhaust emissions from a diesel powered vehicle fuelled by soybean biodiesel blends (B3-B20) with ethanol as an additive (B20E2-B20E5). Fuel 90(1):98-103. https://doi.org/10.1016/j.fuel.2010.09.010

20. Buyukkaya E (2010) Effects of biodiesel on a DI diesel engine performance, emission and combustion characteristics. Fuel 89(10):3099-3105. https://doi.org/10.1016/j.fuel.2010.05.034

21. Vedaraman N, Puhan S, Nagarajan G, Velappan KC (2011) Preparation of palm oil biodiesel and effect of various additives on NOx emission reduction in B20: an experimental study. Int J Green Energy 8(3):383-397. https://doi.org/10.1080/15435 075.2011 .557847

22. Li S, Wang Y, Dong S, Chen Y, Cao F, Chai F, Wang X (2009) Biodiesel production from Eruca sativa Gars vegetable oil and motor, emissions properties. Renewable Energy 34(7):18711876. https://doi.org/10.1016/j.renene.2008.12.020

23. Lapuerta M, Armas O, Rodriguez-Fernandez J (2008) Effect of biodiesel fuels on diesel engine emissions. Prog Energy Combust Sci 34(2):198-223. https://doi.org/10.1016/j. pecs.2007.07.001

24. Dhamodaran G, Krishnan R, Pochareddy YK, Pyarelal HM, Sivasubramanian H, Ganeshram AK (2017) A comparative study of combustion, emission, and performance characteristics of ricebran-, neem-, and cottonseed-oil biodiesels with varying degree of unsaturation. Fuel 187:296-305. https://doi.org/10.1016/j. fuel.2016.09.062

25. Márcio de Almeida D, da Silva MAV, Franca LS, de Oliveira CM, Alexandre MOL, da Costa Marques LG, de Freitas MAV (2017) Comparative study of emissions from stationary engines using biodiesel made from soybean oil, palm oil and waste frying oil. Renew Sustain Energy Rev 70:1376-1392. https://doi. org/10.1016/j.rser.2016.12.040

26. Jaliliantabar F, Ghobadian B, Carlucci AP, Najafi G, Ficarella A, Strafella L, De Domenico S (2018) Comparative evaluation of physical and chemical properties, emission and combustion characteristics of brassica, cardoon and coffee based biodiesels as fuel in a compression-ignition engine. Fuel 222:156-174. https://doi.org/10.1016/j.fuel.2018.02.145

27. Cheikh K, Sary A, Khaled L, Abdelkrim L, Mohand T (2016) Experimental assessment of performance and emissions maps for biodiesel fueled compression ignition engine. Appl Energy 161:320-329. https://doi.org/10.1016/j.apenergy.2015.10.042

28. Ghobadian B, Rahimi H, Nikbakht AM, Najafi G, Yusaf TF (2009) Diesel engine performance and exhaust emission analysis using waste cooking biodiesel fuel with an artificial neural network. Renew Energy 34(4):976-982. https://doi.org/10.1016/j.renen e.2008.08.008

29. Pullen J, Saeed K (2012) An overview of biodiesel oxidation stability. Renew Sustain Energy Rev 16(8):5924-5950. https://doi. org/10.1016/j.rser.2012.06.024

30. Eckhoff RK (2016) Gas and Vapor Cloud Explosions, 2 edn., chap. 2. Gulf Professional Publishing - Elsevier. https://doi. org/10.1016/B978-0-12-803273-2.00002-5.

31. Hirkude JB, Padalkar AS (2012) Performance and emission analysis of a compression ignition: engine operated on waste fried oil methyl esters. Appl Energy 90(1):68-72. https://doi. org/10.1016/j.apenergy.2010.11.028

32. Tripathi S, Subramanian KA (2017) Experimental investigation of utilization of Soya soap stock based acid oil biodiesel in an automotive compression ignition engine. Appl Energy 198:332-346. https://doi.org/10.1016/j.apenergy.2017.02.057

33. Srihari S, Thirumalini S, Prashanth K (2017) An experimental study on the performance and emission characteristics of PCCI$\mathrm{DI}$ engine fuelled with diethyl ether-biodiesel-diesel blends. Renewable Energy 107:440-447. https://doi.org/10.1016/j.renen e.2017.01.015

34. Park SH, Cha J, Lee CS (2012) Impact of biodiesel in bioethanol blended diesel on the engine performance and emissions characteristics in compression ignition engine. Appl Energy 99:334-343. https://doi.org/10.1016/j.apenergy.2012.05.050

35. Alptekin E (2017) Emission, injection and combustion characteristics of biodiesel and oxygenated fuel blends in a common rail diesel engine. Energy 119:44-52. https://doi.org/10.1016/j. energy.2016.12.069

36. Abdalla MM (2013). The potential of Moringa oleifera extract as a biostimulant in enhancing the growth, biochemical and hormonal contents in rocket (Eruca vesicaria subsp. sativa) plants. Int J Plant Physiol Biochem 5(3), 42-49. https://doi.org/10.5897/ IJPPB2012.026

37. Aithal SM (2010) Modeling of NOx formation in diesel engines using finite-rate chemical kinetics. Appl Energy 87(7):22562265. https://doi.org/10.1016/j.apenergy.2010.01.011

38. Ghazali WNMW, Mamat R, Masjuki HH, Najafi G (2015) Effects of biodiesel from different feedstocks on engine performance and emissions: a review. Renew Sustain Energy Rev 51:585-602. https://doi.org/10.1016/j.rser.2015.06.031

Publisher's Note Springer Nature remains neutral with regard to jurisdictional claims in published maps and institutional affiliations. 